\title{
EKSTRAK ETANOL DAUN PANDAN WANGI (Pandanus amaryllifolius Roxb.) SEBAGAI ANTINEFROTOKSISITAS BERDASARKAN PENURUNAN KADAR KREATININ TIKUS
}

\author{
Sukmawati, Ira Asmaliani \\ Fakultas Farmasi Universitas Muslim Indonesia \\ Email : sukmawati.sukmawati@umi.ac.id
}

\begin{abstract}
Nephrotoxicity is a disorder of the kidneys that occurs when exposed to drugs or toxins. Pandan wangi leaves have antioxidant activity expected to give antinephrotoxicity effect. This aim of study is to determine the antinephrotoxicity effect of the ethanol extract of pandan wangi leaves (Pandanus amaryllifolius Roxb.) based on the decline of rat creatinine level induced by gentamicin. Eighteen male Wistar rats were divided into 6 groups. That is naive, negative control by $\mathrm{Na}-\mathrm{CMC} 1 \%$, positive control by the suspension of keto acids, and treatment group with ethanol extract of pandan wangi leaves at $125 \mathrm{mg} / \mathrm{kgBW}, 250 \mathrm{mg} / \mathrm{kgBW}$ and $500 \mathrm{mg} / \mathrm{kgBW}$. Nephrotoxicity condition was induced by Gentamicin $80 \mathrm{mg} / \mathrm{kgBW}$ (ip) for seven days. The blood samples were taken and measured the serum creatinine levels on days $0,8^{\text {th }}$ and $22^{\text {th }}$ by Human Analyzer. The results study showed that ethanol extract of pandan wangi leaves at $250 \mathrm{mg} / \mathrm{kgBW}$ and $500 \mathrm{mg} / \mathrm{kgBW}$ have the effect as antinephrotoxicity based on decreased creatinine levels.
\end{abstract}

Key words : Nephrotoxicity, Pandanus amaryllifolius Roxb., Creatinine, Gentamicin.

\section{PENDAHULUAN}

Salah satu penatalaksanaan penyakit yang paling umum dilakukan adalah penggunaan obat-obatan kimia dengan tujuan promotif, preventif, kuratif dan rehabilitatif. Penggunaan obat yang salah dan berlebihan kemungkinan akan menyebabkan beberapa efek samping pada beberapa fungsi organ. Salah satunya adalah gangguan fungsi ginjal.

$$
\text { Penyakit gagal ginjal adalah suatu }
$$
penyakit dimana fungsi organ ginjal mengalami penurunan. Dalam dunia kedokteran dikenal 2 macam jenis gagal ginjal yaitu gagal ginjal akut dan gagal ginjal kronis. $^{1,2}$ Sedangkan nefrotoksisitas dapat didefinisikan sebagai penyakit ginjal atau disfungsi yang timbul sebagai akibat langsung atau tidak langsung dari paparan obat-obatan, dan bahan kimia industri atau lingkungan. ${ }^{3}$
Gentamisin adalah suatu golongan obat antibiotik aminoglikosida yang digunakan untuk terapi infeksi bakteri.Pada pemberian aminoglikosida selama beberapa hari, 8-26\% mengalami gangguan ginjal ringan yang hampir selalu reversible ${ }^{4}$.Gentamisin berpotensi nefrotoksik akibat berakumulasi di dalam sel epitel tubuler ginjal. ${ }^{5}$ Nefrotoksisitas ringan dan reversibel dapat terjadi pada 5$25 \%$ pasien yang menggunakan obat ini selama 3-5 hari. $^{6}$ Beratnya nefrotoksisitas berhubungan dengan kadar obat yang tinggi dalam plasma. $^{7}$ Insiden gagal ginjal akut disebabkan karena nefrotoksisitas sebesar $15 \%$. Diperkirakan $10 \%$ dari semua kasus gagal ginjal akut disebabkan karena penggunaan antibiotik aminoglikosida. ${ }^{8}$

Penelitian ini dinilai penting karena ginjal sangat rentan terhadap efek toksik obatobatan dan bahan kimia. Sehingga bisa 
Ekstrak etanol daun pandan wangi (Pandanus amaryllifolius Roxb.) sebagai antinefrotoksisitas berdasarkan penurunan kadar kreatinin tikus.

memicu terbentuknya radikal-radikal bebas yang mengarah pada kondisi nefrotoksisitas. ${ }^{9}$ Seperti yang kita ketahui, bahwa ginjal merupakan salah satu organ yang memiliki peranan penting bagi manusia. Fungsi terpenting ginjal yaitumengatur konsentrasi ion-ion penting, mengatur tekanan darah, mengeluarkan zat beracun dan mengeluarkan zat sisa organik, seperti urea, asam urat, kreatinin dan penguraian hemoglobin dan hormon. ${ }^{10}$ Kreatinin adalah suatu metabolit kreatinin dan diekskresi seluruhnya dalam urin melalui filtrasi glomerulus. Dengan demikian, meningkatnya kadar kreatinin dalam darah merupakan indikasi rusaknya fungsi ginjal. ${ }^{11 ; 12}$

Hal tersebut dapat dicegah dengan pemberian antioksidan sintesis maupun yang diperoleh dari bahan alam..$^{9}$ Daun pandan wangi (Pandanus amaryllifolius Roxb.) diduga berpotensi sebagai obat nefroprotektif karena memiliki kandungan senyawa kimia yang bersifat antioksidan seperti alkaloid, flavonoid, tanin, serta polifenol. ${ }^{13}$ Dari hasil penelitian Yan dan Asmah (2010) daun pandan menunjukkan senyawa fenolik yang memiliki aktifitas antioksidan dan aktivitas scavenging pada beberapa radikal bebas. Sedangkan menurut penelitian Margareta dkk. (2011) bahwa aktivitas antioksidan dari ekstrak etanol daun pandan diperoleh denganscavenging activity sebesar $93,21 \%{ }^{14}$

Berdasarkan uraian di atas, maka perlu dilakukan penelitian untuk menentukan efektifitas ekstrak etanol daun pandan wangi (Pandanus amaryllifolius Roxb.) terhadap kadar kreatinin tikus nefrotoksisitas. Kondisi nefrotoksisitas tikus diperoleh dengan menginduksi gentamicin secara intraperitonial.

\section{METODE PENELITIAN}

\section{Jenis Penelitian}

Jenis penelitian yang digunakan yaitu true eksperimental meliputi tiga komponen yaitu kontrol, randomisasi, dan replikasi. Rancangan penelitian yaitu pre-post test control group desain. ${ }^{15}$

\section{Alat dan Bahan}

Alat yang digunakan adalah seperangkat alat maserasi, rotavapor, human analyzer, kuvet, mikropipet, sentrifuge, tabung eppendorf. Sedangkan bahan yang digunakan adalah daun pandan wangi, pakan hewan uji (pellet), aquadest, etanol 96\%, Natrium CMC, gentamisin, ketosteril, dan KIT kreatinin. Hewan uji yang digunakan adalah tikus putih (Rattus norvegicus) strain wistar, sehat, bobot badan 180-250 gram, berusia 2 bulan sebanya 18 ekor.

\section{Prosedur Kerja}

Pembuatan ekstrak etanol daun Pandan Wangi (Pandanus amaryllifolius Roxb.)

Sebanyak 200 gram simplisia dimaserasi dengan etanol 70\% $1000 \mathrm{~mL}$ selama $5 \times 24$ jam, kemudian disaring dan ampasnya direndam kembali dengan cairan penyari yang baru, hasil penyarian yang diperoleh dipekatkan dengan menggunakan rotavapor sampai diperoleh ekstrak etanol pekat, kemudian diuapkan lagi hingga didapatkan ekstrak kental dan ditimbang.

\section{Pembuatan suspensi ketosteril}

Ketosteril ditimbang sebanyak 407,257 mg kemudian disuspensikan dengan $10 \mathrm{~mL} \mathrm{Na} \mathrm{CMC} 1 \%$.

\section{Pembuatan suspensi Na-CMC $1 \%$}

$\begin{array}{llll}\text { Sebanyak } 1 \text { gram Na.CMC } & \end{array}$ dimasukkan sedikit demi sedikit kedalam 50 $\mathrm{mL}$ air air suling panas $\left(70^{\circ} \mathrm{C}\right)$ sambil diaduk dengan menggunakan pengaduk elektrik 
Ekstrak etanol daun pandan wangi (Pandanus amaryllifolius Roxb.) sebagai antinefrotoksisitas berdasarkan penurunan kadar kreatinin tikus.

hingga terbentuk larutan koloidal yang homogen, kemudian dicukupkan volumenya hingga $100 \mathrm{~mL}$ dengan air suling. ${ }^{16}$

Pembuatan ekstrak etanol daun pandan wangi (Pandanus amaryllifolius Roxb.) dosis $125 \mathrm{mg} / \mathrm{kgBB} ; 250 \mathrm{mg} / \mathrm{kgBB}$ dan 500 $\mathrm{mg} / \mathrm{kgBB}$

Ekstrak etanol daun pandan wangidosis $125 \mathrm{mg} / \mathrm{kgBB}$ dibuat dengan cara ekstrak ditimbang sebanyak $125 \mathrm{mg}$, selanjutnya disuspensikan dengan $10 \mathrm{~mL} \mathrm{Na-}$ CMC 1\%. Sedangkan untuk dosis 250 $\mathrm{mg} / \mathrm{kgBB}$ dan $500 \mathrm{mg} / \mathrm{kgBB}$ masing-masing ekstrak ditimbang sebanyak $250 \mathrm{mg}$ dan 500 $\mathrm{mg}$, selanjutnya disuspensikan dengan $10 \mathrm{~mL}$ Na-CMC 1\% .

\section{Perlakuan terhadap hewan coba}

Tikus dibagi dalam 6 kelompok perlakuan secara random allocation yaitu 1 kelompok normal dan 5 kelompok nefrotoksisitas. Masing -masing kelompok terdiri dari 4 ekor tikus. Tahap pertama, pada hari ke-0 semua tikus diambil darahnya dan diukur kadar kreatininnya sebagai data awal. Selanjutnya tikus dalam kelompok perlakuan normal diberikan aquadest secara oral selama 7 hari, sedangkan semua tikus dalam kelompok perlakuan nefrotoksisitas diberikan injeksi gentamisin secara intraperitonial selama 7 hari untuk menginduksi kondisi nefrotoksisitas. Pada hari ke-8, semua tikus diambil darahnya dan diukur kadar kreatininnyasebagai data setelah induksi. Tahap selanjutnya dilakukan selama 14 hari dengan perlakuan sebagai berikut dan pada hari ke-23, semua tikus diambil darahnya dan diukur kadar kreatininnya.

1. Kelompok I : Tikus diberikan NaCMC1 \% secara oral.
2. Kelompok II : Tikus diberikan NaCMC $1 \%$ secara oral.

3. Kelompok III : Tikus diberikan suspensi ketosteril secara oral.

4. Kelompok IV : Tikus diberikan ekstrak etanol daun pandan wangi (EDPW)125 $\mathrm{mg} / \mathrm{kg}$ BB secara oral .

5. Kelompok V: Tikus diberikan ekstrak etanol daun pandan wangi (EDPW) 250 $\mathrm{mg} / \mathrm{kg}$ BB secara oral .

6. Kelompok VI: Tikus diberikan ekstrak etanol daun pandan wangi (EDPW) 500 $\mathrm{mg} / \mathrm{kg}$ BB secara oral .

\section{Prosedur pengambilan sampel darah hewan uji}

Pengambilan sampel darah dilakukan melalui vena lateralis ekor. Sampel darah diambil sebanyak $0,5 \mathrm{~mL}$ yang ditampung dalam tabung Eppendrorf. Setelah itu, sampel darah disentrifuge dengan kecepatan 10.000 rpm selama 10 menit kemudian diambil serum darahnya.

\section{Pengukuran Kreatinin Darah Hewan Uji}

Pengukuran kreatinin dengan cara ditambahkan reagen I sebanyak $100 \mu \mathrm{L}$ dan reagen II sebanyak $100 \mu \mathrm{L}$. Setelah itu, dihomogenkan dan diinkubasi selama 25 detik dan ditambahkan serum sebanyak $20 \mu \mathrm{L}$. Kemudian dihomogenkan dan diinkubasi selama 2 menit. Setelah itu, diukur kreatinin pada alat Fotometer (microlab 300). Kadar normal kreatinin tikus wistar adalah 0,2-0,8 $\mathrm{mg} / \mathrm{dL}$.

\section{Analisis data}

Data yang diperoleh dianalisis secara statistik dengan program Microsoft Office Excell. 
Ekstrak etanol daun pandan wangi (Pandanus amaryllifolius Roxb.) sebagai antinefrotoksisitas berdasarkan penurunan kadar kreatinin tikus.

HASIL DAN PEMBAHASAN:

Tabel 1. Data hasil pengukuran kadar kreatinin tikus selama 22 hari

\begin{tabular}{cccc}
\hline \multirow{2}{*}{ Kelompok } & \multicolumn{3}{c}{ Kadar Kreatinin Darah $(\mathbf{m g} / \mathbf{d L})$} \\
\cline { 2 - 4 } & Hari ke 0 & Hari ke 8 & Hari ke 22 \\
\hline Normal & 0,47 & 0,45 & 0,37 \\
Kontrol Negatif & 0,57 & 2,94 & 3,57 \\
Kontrol Positif & 0,40 & 3,02 & 0,32 \\
EDPW 125 mg/kg BB & 0,52 & 1,02 & 0,27 \\
EDPW 250 mg/kgBB & 0,42 & 2,81 & 0,2 \\
EDPW 500 mg/kgBB & 0,58 & 4,96 & 0,3 \\
\hline
\end{tabular}

Keterangan: EDPW $=$ Ekstrak Daun Pandan Wangi

Tabel 2. Data persen penurunan kadar kreatinin tikus setelah perlakuan selama 14 hari

\begin{tabular}{cc}
\hline Kelompok & Persentase penurunan \\
\hline Normal & 0,08 \\
Kontrol Negatif & $-0,63$ \\
Kontrol Positif & 2,7 \\
EDPW $125 \mathrm{mg} . / \mathrm{kg} \mathrm{BB}$ & 0,75 \\
EDPW $250 \mathrm{mg} / \mathrm{kgBB}$ & 2,61 \\
EDPW $500 \mathrm{mg} / \mathrm{kgBB}$ & 4,66 \\
\hline
\end{tabular}

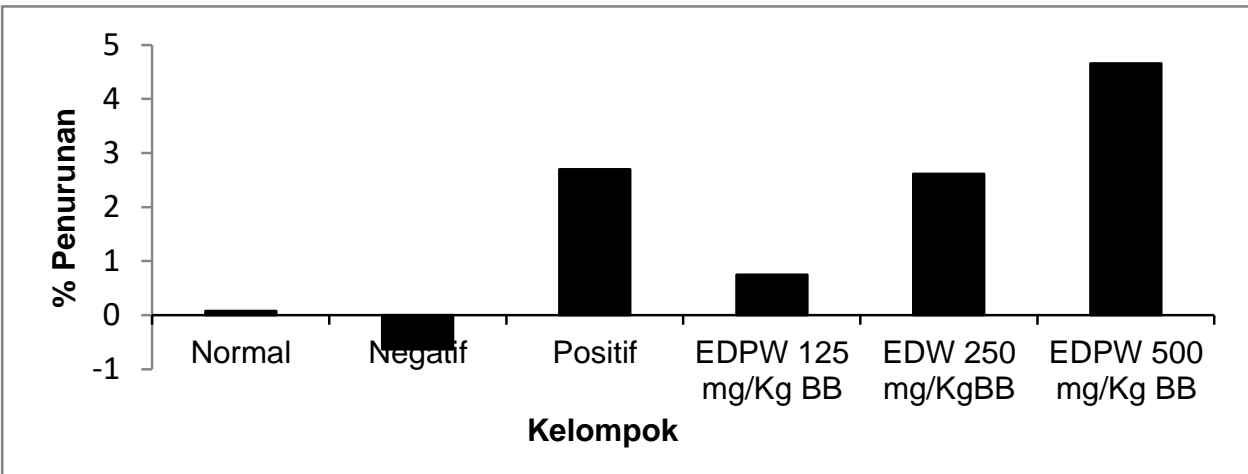

Gambar 1. Grafik persentase penurunan kadar kreatinin tikus setelah perlakuan 14 hari.

Penyakit gagal ginjal merupakan penyakit yang cukup serius dan kronis, penyakit gagal ginjal ini timbul karena kemungkinan adanya infeksi atau luka pada ginjal itu sendiri. Penyakit gagal ginjal dapat menyerang siapa saja terutama lebih sering pada mereka yang masih berusia dewasa, adapun penyebab dari penyakit gagal ginjal yaitu adanya penyakit lain yang berdampak langsung pada organ-organ ginjal ${ }^{17}$. Penelitian ini dilakukan untuk menentukan efektifitas ekstrak etanol daun pandan wangi (Pandanus amaryllifolius Roxb.) terhadap kadar kreatinin tikus nefrotoksisitas. Penelitian ini menggunakan hewan uji tikus putih jantan sebanyak 24 ekor.

Hewan sebelumnya diadaptasi selama 1 minggu pada lingkungan laboratorium. Sebelum perlakuan, hewan uji dipuasakan selama 6-12 jam untuk menghindari adanya pengaruh makanan terhadap hasil penelitian, kemudian diambil darah hewan uji untuk 
Ekstrak etanol daun pandan wangi (Pandanus amaryllifolius Roxb.) sebagai antinefrotoksisitas berdasarkan penurunan kadar kreatinin tikus.

pengukuran kadar kreatinin awal. Dari 24 ekor tikus dibagi dalam 6 kelompok perlakuan. Pada hari 0-8 semua kelompok diberi gentamisin dengan dosis $100 \mathrm{mg} / \mathrm{kgBB}$ secara intra peritoneal. Kelompok I yang merupakan kelompok kontrol normal hanya diberi $\mathrm{Na}$ CMC $1 \%$, hal ini bertujuan untuk melihat apakah Na-CMC tidak memberikan efek fisiologis bagi hewan coba serta alasan penggunaan Na-CMC dilihat dari pembawa sediaan uji lainnya, kelompok II sebagai kontrol negatif diberi obat gentamisin dengan tujuan untuk meningkatkan kadar kreatinin pada tikus, kelompok III diberi obat ketosteril sebagai kontrol positif yang mana berfungsi sebagai pembanding untuk menentukan apakah sampel yang digunakan memiliki efek nefroterapi yang sama dengan obat ketosteril. Sedangkan kelompok IV, V dan VI merupakan kelompok perlakuan yang diberi sampel ekstrak ekstrak etanol daun pandan wangi (Pandanus amaryllifolius Roxb.) dengan dosis yang bervariasi masing-masing dosisnya yaitu $125 \mathrm{mg} / \mathrm{kgBB}, 250 \mathrm{mg} / \mathrm{kgBB}$ dan 500 $\mathrm{mg} / \mathrm{kgBB}$. Variasi dosis ini berfungsi untuk membandingkan dosis yang efektif sebagai nefroterapi. Kemudian pada hari ke-8 dan hari ke 22 sampel darah diambil dan diukur kadar kreatinin serum. Hasil pengukuran setelah terapi menunjukkan adanya penurunan kadar kreatinin, hal ini berarti adanya perbaikan fungsi ginjal.

Hasil pengukuran kadar kreatinin tikus dapat dilihat pada tabel 1 yang menunjukkan bahwa terjadi peningkatan rata-rata kadar kreatinin pada semua kelompok kecuali pada kelompok kontrol normal serta diplot dalam sebuah diagram dapat dilihat pada gambar 1 yang menunjukkan dengan jelas perbedaan dari setiap kelompok. Hal itu membuktikan bahwa gentamisin dengan dosis $100 \mathrm{mg} / \mathrm{KgBB}$ dapat meningkatkan kadar kreatinin. Peningkatan ini terjadi karena gentamisin merupakan suatu golongan obat antibiotik aminoglikosida yang digunakan untuk terapi infeksi bakteri, obat ini memiliki efek toksik dan efek samping yang sama dengan aminoglikosida lainnya. Gentamisin berpotensi nefrotoksik akibat berakumulasi di dalam sel epitel tubuler ginjal. ${ }^{5}$ Gentamisin mempunyai rentang terapi sempit, yang bersifat ototoksik serta mempunyai variabilitas farmakokinetik individu cukup lebar, maka pemantauan kadar obat dalam darah pada penderita dengan gangguan fungsi ginjal adalah suatu kebutuhan agar keamanan dan efikasi terapi tercapai. $^{18}$

Berdasarkan nilai persen penurunan, kelompok ekstrak dosis $250 \mathrm{mg} / \mathrm{kgBB}$ dan 500 $\mathrm{mg} / \mathrm{kgBB}$ menunjukkan penurunan berturutturut sebesar 2,61\%, dan 4,66 \% (tabel 2). Ekstrak dosis $500 \mathrm{mg} / \mathrm{kgBB}$ menunjukkan penurunan kadar kreatinin yang paling baik. Penurunan ini disebabkan karena adanya kandungan flavonoid pada ekstrak daun sukun yang berkhasiat dalam pengobatan gagal ginjal. Selain itu juga, flavonoid memiliki aktifitas dalam meningkatkan fungsi penyaringan dan kecepatan filtrasi glomerulus sehingga dapat mengeluarkan zat-zat racun yang terdapat pada ginjal yang efeknya dapat mengurangi kerusakan ginjal. ${ }^{19}$ Jadi dapat dikatakan bahwa dengan pemberian senyawa ekstrak flavonoid dapat digunakan sebagai obat gagal ginjal.

\section{KESIMPULAN}

Berdasarkan hasil penelitian dan pembahasan disimpulkan bahwa pemberian ekstrak etanol daun pandan wangi (Pandanus amaryllifolius Roxb.) dapat menurunkan kadar 
Ekstrak etanol daun pandan wangi (Pandanus amaryllifolius Roxb.) sebagai antinefrotoksisitas berdasarkan penurunan kadar kreatinin tikus.

kreatinin tikus nefrotoksisitas. Ekstrak etanol daun pandan wangi (Pandanus amaryllifolius Roxb.) dosis $250 \mathrm{mg} / \mathrm{kg} \mathrm{BB}$ dan $500 \mathrm{mg} / \mathrm{kgBB}$ yang efekif dapat menurunkan kadar kreatinin tikus nefrotoksisitas.

\section{DAFTAR PUSTAKA}

1. Widyati. Pharmaceutical Care pada Gagal Ginjal. In Widyati. Praktik Farmasi Klinik . Surabaya: Brilian Internasional, 2013.

2. Price SA, \& Wilson LM. Patofisiologi, Konsep Klinis Proses-Proses Penyakit Edisi IV. Jakarta: EGC, 1994.

3. Purwitasari R. Efek Nefroprotektif Ekstrak Daun Karamunting (Rhodomyrtus tomentosa (aiton) Hassk.) Terhadap Nefrotoksisitas Yang Diinduksi Asetaminofen. Jurnal Mahasiswa PSPD FK Universitas Tanjungpura. 2015;3(1).

4. Mac Dougall C, Chambers HF. Aminoglycosides. In C. B. Brunton LL, The Pharmacological Basis of Therapeutics (Twelfth Edition). New York: Mc.Graw Hill Medical, 2011.

5. Giguere S. Antimicrobial Therapy in Veterinary Medicine Fourth Edition. 2006. Retrieved April 25, 2017.From http://books google.co.id.

6. Chambers HF. Aminoglikosida \& Spektinomisin. In e. Katzung Bertram G, Basic and Clinical Pharmaco-logy (Tenth Edition). Jakarta: EGC, 2007.

7. Lintong PM, Kairupan CF, Sondakh PL. Gambaran Mikroskopik Ginjal Tikus Wistar (Rattus norvegicus) Setelah Diinduksi Dengan Gentamisin. Jurnal Biomedik. 2012;4(3):185-192.

8. Hewitt WR, Goldstein RS, Hook JB. Toxic responses of the kidney. In D. J. Amdes MO, Casarett and Doull's Toxicology The Basic Science of Poisons. (Fourth Edition). New York: Mc. Graw Hill, Inc., 1991.

9. Julianty DR. Uji Efek Nefroprotektif Umbi Ubi Jalar Ungu (Ipomoea batatas L.) dengan Parameter Kadar Kreatinin pada Tikus Putih (Rattus norvegicus) yang Diinduksi Parasetamol (Skripsi). Makassar: Universitas Muslim Indonesia, 2016.
10. Sloane E. Anatomi dan Fisiologi untuk Pemula. Jakarta: Penerbit Buku Kedokteran EGC, 2004.

11. Dipiro JT, Talbert RL, Yee GC, Matzke GR, Wells BG, Posey LM. Pharmacotherapy A Pathophysiologic Approach, 8 th Edition. United States of America: The McGraw-Hill Companies Inc., 2011.

12. Kadrina. Uji Efek Ekstrak Etanol Daun Sukun (Artocarpus altilis) Terhadap Penurunan Kadar Ureum Tikus Yang Diinduksi Gentamisin (Skripsi). Makassar: Universitas Muslim Indonesia, 2016.

13. Prameswari OM \& Widjanarko SB. Uji Efek Ekstrak Air Daun Pandan Wangi Terhadap Penurunan Kadar Glukosa Darah Dan Histopatologi Tikus Diabetes Mellitus. Jurnal Pangan dan Agroindustri. 2014;2(2):16-27.

14. Margaretta, S, Handayani SD, Indraswati $\mathrm{N}$, \& Hindarso $\mathrm{H}$. Ekstraksi senyawa phenolic Pandanus amaryllifolius Roxb. Sebagai antioksidan alami. Widya Teknik. 2011.10(1):21-30.

15. Zainuddin M. Metodologi Penelitian: Kefarmasiaan dan Kesehatan. Surabaya: Airlangga University Press., 2011.

16. Parrot EL. Pharmaceutical Technology Fundamental Pharmaceutics. Minnepolis: BurgessPublishing Company., 1979.

17. Soemyarso N, Noer MS. Gagal ginjal akut pada nonatus. Lab/SMF IImu Kesehatan Anak FK UNAIR/RSU Dr Soetomo. 2004, September 24 (Cited 2007, November 27).

18. Sweeney RW, MacDonald M, Hall J, Divers TJ, Sweeney CR. Kineticks of Gentamicin Elimination in Two Horses with Acute Renal Failure. Equine Vet J. 1988;20(3):182-4.

19. Shao-Yu Z, Nai-Ning S, Wen-Yuan G, Wei $J$, Hong-Quan D, Pei-Gen X. Progress in The Treatment Ofchronic Glomerulonephritis Withtraditional Chinese Medicine. Asian Journal of Pharmacodynamic and Pharmacokinetics. 2006;6(4):317-325. 